\title{
AFLP analysis of genetic diversity in five accessions of Polish runner bean (Phaseolus coccineus $\mathbf{L}$.)
}

\author{
M. Boczkowska $\cdot$ Z. Bulińska-Radomska $\cdot$ \\ J. Nowosielski
}

Published online: 10 February 2012

(C) The Author(s) 2012. This article is published with open access at Springerlink.com

\begin{abstract}
Runner bean (Phaseolus coccineus L.) is traditionally cultivated in Poland for dry seeds. The national collection of runner bean maintained in the National Center for Plant Genetic Resources gathers 152 accessions, which are mainly landraces originated in Poland (68\%), Ukraine (17\%) and Slovakia (10\%). The collection contains valuable genetic resources for bean breeders and research. The aim of this study was to describe the level and structure of genetic diversity of three landraces and two commercial cultivars of runner bean from the national collection in order to assess their genetic potential for breeding. Amplified Fragment Length Polymorphism analysis included five combinations of selective primers. Analysis of seven genetic diversity parameters reveled fair amount of genetic variation both in landraces and cultivars. High genetic diversity of commercial cultivars relative those of landraces suggests that the breeding process leading to their release was rather moderate and most likely included domestic gene pool of runner bean. Low gene diversity and low Nei's genetic distance values as well as intergradations among accessions in the PCoA may indicate reduced variability
\end{abstract}

M. Boczkowska (凹) · Z. Bulińska-Radomska .

J. Nowosielski

National Centre for Plant Genetic Resources, Plant

Breeding and Acclimatization Institute, Radzików, 05-870 Błonie, Poland

e-mail: maja.boczkowska@gmail.com
$P$. coccineus grown in Poland as a result of its migration pathways.

Keywords AFLP - Genetic diversity - Phaseolus coccineus Population structure

\section{Introduction}

Runner bean (Phaseolus coccineus L.) was introduced to Europe from Central America. It is a perennial species but in Polish climatic conditions (transitional, temperate climate) it shows annual habit of growth because its tuberous root system does not survive cold winters (Łabuda 2010). The tradition of growing runner bean on Polish territory goes back to the sixteenth century when it was initially grown as an ornamental and medicinal plant in monastery gardens. In the twentieth century, for many years Polish market was dominated by one cultivar "Piękny Jaś" but in the less agriculturally advanced southern and south-eastern regions numerous landraces were commonly cultivated by farmers (Łabuda 2010). Over the past 20 years substantial progress was made in runner bean breeding leading to the registration of seven new cultivars in the National Catalogue. Currently in Poland runner and common bean commercial cultivation makes more than half of the legume seed production for human consumption, however, economic importance of the runner bean is lower than that of the common bean. Runner bean is traditionally 
cultivated for the dry seeds. Consumers in Poland are accustomed to the specific taste of its large seeds. In Polish cuisine dry bean seeds are used for making soup, casseroles, salads, appetizers and variety of hot main course dishes. Climbing forms of runner bean are often grown in home gardens as an ornamental vine plant because of its magnificent inflorescences with white or red flowers.

Phaseolus collection of the National Programme of Plant Genetic Resources located at the National Centre for Plant Genetic Resources at Radzików (Poland), consists of valuable genetic resources for bean breeders and research. It includes nearly 3,000 accessions, of which 152 belong to $P$. coccineus. The accessions of runner bean are mainly landraces originated in Poland (68\%), Ukraine (17\%) and Slovakia (10\%). Majority of landraces were collected in the south and southeast and to lower extent in central regions of Poland which are main areas for runner bean cultivation. During expeditions conducted in the years 1976-1979 regions of occurrence of old cultivars and landraces were determined. Most of them were located in the southern part of Poland, especially in the Tatra and Beskidy mountains and their forelands (Hanelt and Hammer 1977; Hammer and Hanelt 1979; Kulpa and Hanelt 1981; Hanelt and Schultze-Motel 1979; Kulpa and Jastrzębski 1986; Kulpa and Górski 1986).

Runner bean is a carrier of genes for resistance to many diseases caused by fungi (Ascochyta, Sclerotinia sclerotiorum, Fusarium, Phaeoisariopsis griseola, Colletotrichum) (Schmit and Baudoin 1992; Gilmore et al. 2002; Wallace and Wilkinson 1965; Abawi et al. 1978; Silbernagel and Hannan 1992; Mahuku et al. 2002, 2003), bacteria (Xanthomonas) (Miklas et al. 1994) and virus (Bean golden yellow mosaic virus) (Osorno et al. 2003). There is some evidence on successful experiments transferring the resistance genes from runner bean to common bean (Miklas et al. 1994, 1998, 1999; Wallace and Wilkinson 1965).

The aim of this research was to describe the level and structure of genetic diversity of three landraces of runner bean collected in Poland versus two commercial cultivars in order to assess their genetic potential for breeding and to complement earlier study by Nowosielski et al. (2002) on characterization of genetic diversity of domestic Phaseolus germplasm.

\section{Materials and methods}

Materials

Plant material used in this study consisted of five accessions of runner bean from the Polish gene bank collection. Three landraces included in this study were collected in Małopolska Highlands and Beskidy regions located westwards from the collection sites of landraces investigated by Nowosielski et al. (2002). The two commercial cultivars Eureka and Blanka were included in the analysis because they proved to be successfully grown at the time of the collection of landraces and remained in cultivation long afterwards (Table 1). Each accession was represented by 15 plants grown under greenhouse conditions.

\section{Molecular analysis}

For AFLP (Amplified Fragment Length Polymorphism) analysis total DNA was isolated from leaf tissue of 6-week old individual seedlings using DNeasy Plant Mini Kit (Qiagen), in accordance with

Table 1 Descriptions of five runner bean accessions used in the study

\begin{tabular}{llllll}
\hline Accession number & Accession name & Collection date & Seed coat colour & Sample status & Collection site/breeding company \\
\hline 180500 & BES 003 & 1997 & White & Landrace & $\begin{array}{l}\text { Kocierz Moszczanicki, } \\
49^{\circ} 45^{\prime} \mathrm{N} ; 19^{\circ} 16^{\prime} \mathrm{E}\end{array}$ \\
180511 & BES 045 & 1997 & Purple-black & Landrace & Bażanowice, \\
& & & & & $49^{\circ} 44^{\prime} \mathrm{N} ; 18^{\circ} 43^{\prime} \mathrm{E}$ \\
181000 & POLKIE99-035 & 1999 & White & Landrace & Korczyn \\
180152 & & & & $50^{\circ} 55^{\prime} \mathrm{N}, 20^{\circ} 20^{\prime} \mathrm{E}$ \\
180991 & Eureka & 1994 & White & Cultivar & PlantiCo, Szymanów \\
\hline
\end{tabular}


the procedure provided by the producer company. For each accession 15 individuals were analysed.

The AFLP ${ }^{\mathrm{TM}}$ Plant mapping kit (PE Applied Biosystems) was employed in the AFLP reactions according to the manufacturer's protocol. The five most informative primer pairs EcoRI-ACA/MseI-CAT, EcoRI-ACC/MseI-CAG, EcoRI-AAG/MseI-CTA, EcoRIACG/MseI-CAG, EcoRI-ACG/MseI-CTG out of 64 combinations tested were used for selective PCR. All amplification reactions were accomplished using the Biometra T1 Thermocycler at the speed of temperature change $1{ }^{\circ} \mathrm{C} / \mathrm{s}$. Electrophoresis was conducted on $36 \mathrm{~cm}$ long plates in denaturing polyacrylamide gel $(4.5 \%)$ for $4 \mathrm{~h}$ at 2,400 $\mathrm{V}$. The analysis was performed using fluorescent labeling and detecting technology using ABI PRISM 377 XL device (PE Applied Biosystems).

The length of the analyzed fragments, ranging from 35 to $500 \mathrm{bp}$, was determined using GENESCAN software with accuracy of $1 \mathrm{bp}$, and the minimum accepted height of the peak was 100 points. The detected DNA fragments were converted into the zeroone matrix, where $1=$ presence and $0=$ absence, using the MS Excel 2003 software.

\section{Data analysis}

Analysis of data was performed using seven measuring parameters: total number of detected loci (Loc), number of polymorphic loci at the 5\% level (Loc_P) i.e., loci with allelic frequencies ranging from 0.05 to 0.95 , proportion of polymorphic loci (PLP) at the $5 \%$ level expressed as a percentage, number of unique loci (Loc_U), proportion of unique loci (PUL) and number of loci/individual (Loc/n). AFLPsurv (Vekemans et al. 2002) software was used to estimate the number (Loc_P) and proportion (PLP) of polymorphic loci at

Table 2 Parameters of genetic diversity (Loc-number of scored loci; Loc_P-number of polymorphic loci, PLP-proportion of polymorphic loci; Loc_U-number of unique loci; PUL- the $P=0.05$, Nei's gene diversity $(\mathrm{Hj})$; expected heterozygosity under Hardy-Weinberg equilibrium, and Nei's genetic distances between accessions (after Lynch and Milligan 1994a, b).

Analysis of Molecular Variance (AMOVA) and the Principal Coordinate Analysis (PCoA) were performed, using genetic distance values, by the GenAlex 6.2 software (Peakall and Smouse 2006).

\section{Results and discussion}

Genetic diversity within landraces and cultivars

The five primer pair combinations used in this study produced 916 (98.4\% polymorphic) scorable PCR products in the whole data set. Out of the total number of analyzed loci, $22.8 \%$ were common to all accessions, $14.5 \%$ were unique to BES $045,13.2 \%$ to POLKIE99-035, 4.1\% to Blanka, 2.5\% to BES 003 and $2.1 \%$ to Eureka.

The analysis reveled fair amount of genetic variation both in landraces and cultivars (Table 2). The two dwarf Polish commercial cultivars Eureka and Blanka did not differ substantially from the landraces in terms of the number and the proportion of polymorphic loci, the number of loci/plant and the gene diversity parameter $\mathrm{Hj}$. They had, however, much lower proportion of unique loci than two landraces. Modern cultivars, especially those of major cultivated species, display lower level of diversity and lower number of unique loci relative to landraces and natural populations resulting from intensive directional breeding manipulations (Beebe et al. 2001; Metais et al. 2002). Both aforementioned cultivars belong to fairly "old ones" as they were released in 1991/1994 by the same breeding company. While Eureka has been

proportion of unique loci; Loc/n-number of scored loci/ individual, $\mathrm{Hj}$-Nei s gene diversity)

\begin{tabular}{|c|c|c|c|c|c|c|c|}
\hline Accession & Loc & Loc_P & PLP $(\%)$ & Loc_U & PUL & Loc/n & $\mathrm{Hj}$ \\
\hline POLKIE99-035 & 632 & 494 & 53.9 & 121 & 13.2 & 302.5 & 0.196 \\
\hline BES 045 & 481 & 411 & 44.9 & 133 & 14.5 & 278.4 & 0.150 \\
\hline Blanka & 509 & 404 & 44.1 & 38 & 4.1 & 278 & 0.163 \\
\hline BES 003 & 442 & 363 & 39.6 & 23 & 2.5 & 222 & 0.148 \\
\hline Eureka & 432 & 432 & 47.2 & 19 & 2.1 & 226.2 & 0.158 \\
\hline
\end{tabular}


Table 3 Results of Analysis of Molecular Variance (AMOVA)

\begin{tabular}{lrllr}
\hline Source & $d f$ & Sum of squares & Variance components & Percentage of variation \\
\hline Among accessions & 4 & $1,008.614$ & 16.800 & 40.82 \\
Within accessions & 63 & $1,534.830$ & 24.362 & 59.18 \\
Total & 67 & $2,543.444$ & 41.163 & 100 \\
\hline
\end{tabular}

successfully cultivated ever since, Blanka following long period of its commercial use was withdrawn from the National Register of Cultivated Plants in 2008. Their relatively high genetic diversity, comparable to those of landraces, suggests that the breeding process leading to their release was rather moderate and most likely included domestic gene pool of runner bean. Poland has a long tradition of breeding cultivars on the basis of landraces, its origins date back to the second decade of last century (Kulpa and Hanelt 1981). The lowest values of the genetic diversity parameters for the landrace BES 003 are difficult to explain considering scarcity of information on its cultivation, collecting and seed handling in the gene bank. Gene diversity values $(\mathrm{Hj})$ for all accessions fell below those for Italian landraces revealed by RAPD, ISSR, SSR and ET markers by Acampora et al. (2007), Spataro et al. (2011), Escalante et al. (1994). This finding may provide additional support to the hypothesis on evolutionary pathways of runner bean in Europe presented by Spataro et al. (2011). According to that, the European continent could be regarded as a secondary diversification centre for runner bean and the crop was initially introduced to Iberian peninsula and immediately afterwards to Italian peninsula from where it was distributed to the North and East. If this was the case then the migration northwards must have involved adaptation to the new environmental conditions and also selection by the consumers dietary preferences which most likely resulted in the reduction of variability and formation of new gene combinations.

Genetic differentiation of landraces and cultivars

The AMOVA revealed significant variation among and within accessions at $P=0.01$ level. Over half of the total variance $(59.18 \%)$ was located within accessions leaving $40.82 \%$ to variability among accessions (Table 3), as it could have been expected for an allogamous species. However, disproportion between these two components was not as pronounced as that

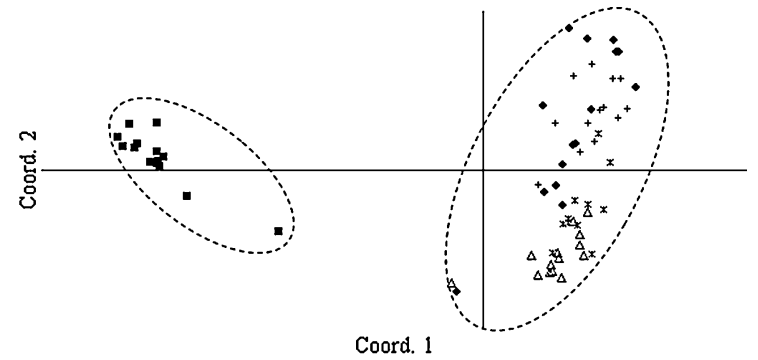

- POLKIE99-35 - BES $045+$ Blanka $\triangle$ BES 003 × Eureka

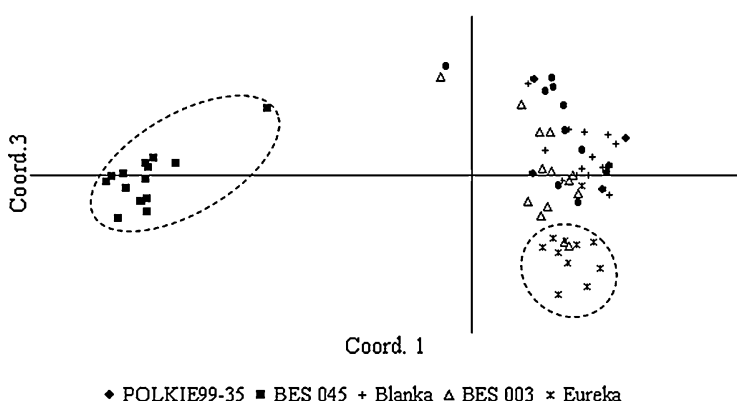

Fig. 1 Principal Coordinate Analysis of AFLP data

found by Acampora et al. (2007) using three marker systems (RAPD, ISSR and ET) in Italian and American accessions.

In PCoA $78.96 \%$ of the total variance was accounted by the first three coordinates (49.8, 22.9 and $9.1 \%$, respectively). The first and the second coordinates differentiated the landrace BES 045 form the other accessions. Remaining four accessions were intermixed with extensive overlap of BES 003 with Eureka and POLKIE99-035 with Blanka. The first and the third coordinates separated Eureka from Blanka, BES 003 and from POLKIE99-035 (Fig. 1). It was also shown that none of the accessions except for BES 045 presented distinct genetic makeup.

The distinctive gene pool of BES 045 landrace is ascribed to its genetic background. This landrace is characterized by red flowers and a purple-black seeds whereas the remaining accessions by white flowers and seeds. According to Santalla et al. (2002) red flower forms belong to Phaseolus coccineus var. 
Table 4 Nei's genetic distance between accessions

\begin{tabular}{llllll}
\hline Accession & $\begin{array}{l}\text { POLKIE99- } \\
35\end{array}$ & $\begin{array}{l}\text { BES } \\
045\end{array}$ & Blanka & $\begin{array}{l}\text { BES } \\
003\end{array}$ & Eureka \\
\hline $\begin{array}{l}\text { POLKIE99- } \\
\quad-\end{array}$ & & & & & \\
BES 045 & 0.175 & - & & & \\
Blanka & 0.023 & 0.170 & - & & \\
BES 003 & 0.062 & 0.166 & 0.064 & - & \\
Eureka & 0.065 & 0.162 & 0.058 & 0.014 & - \\
\hline
\end{tabular}

coccineus, whereas white flower ones to Phaseolus coccineus var. albiflorus. Similar results with regards to genetic dissimilarity between red and white type flower forms were obtained by ISSR technique for nine landraces from central Italy (Sicard et al. 2005).

Nei's genetic distance values ranged from 0.014 to 0.175 (Table 4). It also did not discriminate commercial cultivars from landraces. The relatively low genetic differentiation expressed by the low values of the genetic distance between accessions (average 0.048) except BES 045 landrace (average 0.167) is in agreement with the results of earlier study of three Polish landraces and two cultivars of runner bean by Nowosielski et al. (2002).

It could be concluded from the results of this two studies that the genetic variation of $P$. coccineus cultivated in Poland might be relatively narrow. A low level of polymorphism among European accessions of runner bean was also observed by Hamann et al. (1995), Sicard et al. (2005) and Acampora et al. (2007). Low gene diversity and low Nei's genetic distance values as well as intergradations among accessions in the PCoA analysis in our study support the hypothesis presented by Spataro et al. (2011).

Open Access This article is distributed under the terms of the Creative Commons Attribution License which permits any use, distribution, and reproduction in any medium, provided the original author(s) and the source are credited.

\section{References}

Abawi GS, Provvidenti R, Crosier DC, Hunter JE (1978) Inheritance of resistance to white mold disease in Phaseolus coccineus. J Hered 69:200-202

Acampora A, Ciaffi M, De Pace C, Rita Paolacci A, Tanzarella OA (2007) Pattern of variation for seed size traits and molecular markers in Italian germplasm of Phaseolus coccineus L. Euphytica 157:69-82
Beebe S, Rengifo J, Gaitan E, Duque MC, Tohme J (2001) Diversity and origin of Andean landraces of common bean. Crop Sci 41:854-862

Escalante AM, Coello G, Eguiarte LE, Pinero D (1994) Genetic structure and mating systems in wild and cultivated populations of Phaseolus coccineus and P. vulgaris (Fabaceae). Am J Bot 81:1096-1103

Gilmore B, Myers JR, Kean D (2002) Completion of testing of Phaseolus coccineus plant introductions (PIs) for white mold, Sclerotinia sclerotiorum, resistance. Annu Rep Bean Improv Coop 45:64-65

Hamann A, Zink D, Nagl W (1995) Microsatellite fingerprinting in the genus Phaseolus. Genome 38:507-515

Hammer K, Hanelt P (1979) Botanische Ergebnisse einer Reise in die VR Polen 1976 zur Sammlung autochthoner Landsorten von Kulturpflanzen. Kulturpflanze 27:109-149

Hanelt P, Hammer K (1977) Bericht über eine Reise nach der VR Polen 1976 zur Sammlung autochthoner Sippen von Kulturpflanzen. Kulturpflanze 27:33-44

Hanelt P, Schultze-Motel J (1979) Bericht über die Reise in die VR Polen 1976 zur Sammlung autochthoner Sippen von Kulturpflanzen in Jahre 1978. Kulturpflanze 27:151-163

Kulpa W, Górski M (1986) Zasoby miejscowych form roślin uprawnych. Cz. II. Wyniki eksploracji zasobów roślinnych północno-wschodniej części Polski w latach 1977 i 1979. Biul IHAR 160:47-55

Kulpa W, Hanelt P (1981) Activities regarding collection and evaluation of Polish landraces. Kulturpflanze 29:81-90

Kulpa W, Jastrzębski A (1986) Zasoby miejscowych form roślin uprawnych Cz.I. Wyniki eksploracji Płaskowyżu Kolbuszowskiego, Pogórza Karpackiego i Beskidów w latach 19976 i 1978. Biul IHAR 160:27-45

Łabuda H (2010) Runner bean (Phaseolus coccineus L.) biology and use. Acta Sci Pol Hortorum Cultus 9:117-132

Lynch M, Milligan BG (1994a) Analysis of population genetic structure with RAPD markers. Mol Ecol 3:91-99

Lynch M, Milligan BG (1994b) Analysis of population genetic structure with RAPD markers. Mol Ecol 3:91-99

Mahuku GS, Jara C, Cajiao C, Beebe S (2002) Source of resistance to Colletotrichum in the secondary gene pool of Phaseolus vulgaris and in crosses of primary and secondary gene pools. Plant Dis 86:1383-1387

Mahuku G, Jara C, Cajiao C, Beebe S (2003) Sources of resistance to angular leaf spot (Phaeoisariopsis griseola) in common bean core collection, wild Phaseolus vulgaris and secondary gene pool. Euphytica 130:303-313

Metais I, Hamon B, Jalouzot R, Peltier D (2002) Structure and level of genetic diversity in various bean types evidenced with microsatellite markers isolated from a genomic enriched library. Theor Appl Genet 104:1346-1352

Miklas PN, Beaver JS, Grafton KF, Freytag GF (1994) Registration of TARS VCI-4B multiple disease resistant dry bean germplasm. Crop Sci 34:1415

Miklas PN, Grafton KF, Kelly JD, Steadman JR, Silbernagel MJ (1998) Registration of four white mold resistant dry bean germplasm lines: I9365-3, I9365-5, I9365-31, and 92BG-7. Crop Sci 38:1728

Miklas PN, Zapata M, Beaver JS, Grafton KF (1999) Registration of four dry bean germplasm resistant to common bacterial blight: ICB-3, ICB-6, ICB-8, and ICB-10. Crop Sci 39:594 
Nowosielski J, Podyma W, Nowosielska D (2002) Molecular research on the genetic diversity of Polish varieties and landraces of Phaseolus coccineus L. and Phaseolus vulgaris L. using the RAPD and AFLP methods. Cell Mol Biol Lett 7:753-762

Osorno JM, Beaver JS, Ferwerda FH, Miklas PN (2003) Two genes from Phaseolus coccineus L. confer resistance to bean golden yellow mosaic virus. Annu Rep Bean Improv Coop 46:147-148

Peakall R, Smouse PE (2006) GENALEX 6: genetic analysis in Excel. Population genetic software for teaching and research. Mol Ecol Notes 6:288-295

Santalla M, Rodino P, De Ron M (2002) Allozyme evidence supporting southwestern Europe as a secondary centre of genetic diversity for the common bean. Theor Appl Genet 104:934-944

Schmit V, Baudoin JP (1992) Screening for resistance to Ascochyta blight in populations of Phaseolus coccineus L. and $P$. polyanthus Greenman. Field Crop Res 30:155-165
Sicard D, Nanni L, Porfiri O, Bulfon D, Papa R (2005) Genetic diversity of Phaseolus vulgaris $\mathrm{L}$. and P. coccineus $\mathrm{L}$. landraces in Central Italy. Plant Breed 124:464-472

Silbernagel MJ, Hannan RM (1992) Use of plant introductions to develop U.S. bean cultivars. In: Shands HL Wiesner LE (eds) Use of plant introductions in cultivar development. Part 2. CSSA, Madison, pp 1-8

Spataro G, Tiranti B, Arcaleni P, Bellucci E, Attene G, Papa R, Spagnoletti Zeuli P, Negri V (2011) Genetic diversity and structure of a worldwide collection of Phaseolus coccineus L. Theor Appl Genet 122:1281-1291

Vekemans X, Beauwens T, Lemaire M, Roldan-Ruiz I (2002) Data from amplified fragment length polymorphism (AFLP) markers show indication of size homoplasy and of a relationship between degree of homoplasy and fragment size. Mol Ecol 11:139-151

Wallace DH, Wilkinson RE (1965) Breeding for Fusarium root rot resistance in beans. Phytopathology 55:1227-1231 